\title{
18
}

\section{Reflections on the social and cultural aspects of the megalithic site of Onto, Bantaeng, South Sulawesi}

\author{
Akin Duli
}

\begin{abstract}
This paper presents the results from an archaeological survey of the megalithic site of Onto in Bantaeng, South Sulawesi. A variety of archaeological remains were found at this site including menhirs, incised stones, rings of stacked stones, stone tablets including a stone altar, dakon stones with circular impressions, royal installation stones, structural stone walls, and pottery (imported and locally made). The surface survey undertaken at Onto documented the boundaries and spatial structure of its cultural remains. The analysis of these remains produced descriptions of each type of artefactual material as well as interpretations of their meaning. This research adds to the available information on the role of Onto in the origins of the early historical kingdom of Bantaeng and to our understanding of settlements attached to megalithic culture in South Sulawesi.
\end{abstract}

Keywords: South Sulawesi early history, megaliths, Bantaeng, Onto

\section{Introduction}

Bantaeng is a small district, covering an area of about $396 \mathrm{~km}^{2}$, located along the southern coast of South Sulawesi about $125 \mathrm{~km}$ from the capital city of Makassar (Figure 18.1). The majority of its $\sim 180,000$ inhabitants belong to the Makasar ethnic group, although many Bugis have immigrated following the defeat of Makassar empire by the United East India Company (VOC) and its Bugis allies in 1667. Both the Makasar and Bugis have adopted Islam following its introduction to the region at the turn of the 17 th century. More than $60 \%$ of the Bantaeng inhabitants work in the agricultural sector predominately growing rice and maize, along with cash crops such as cloves, cotton, cacao and (at higher elevations) potatoes, carrots and the kapok fibre harvested from forest remnants. Much of the remaining population lives near the sea, practising a maritime lifestyle including fishing (Bougas 1998; Nayati 2005; Wikipedia 2017). 


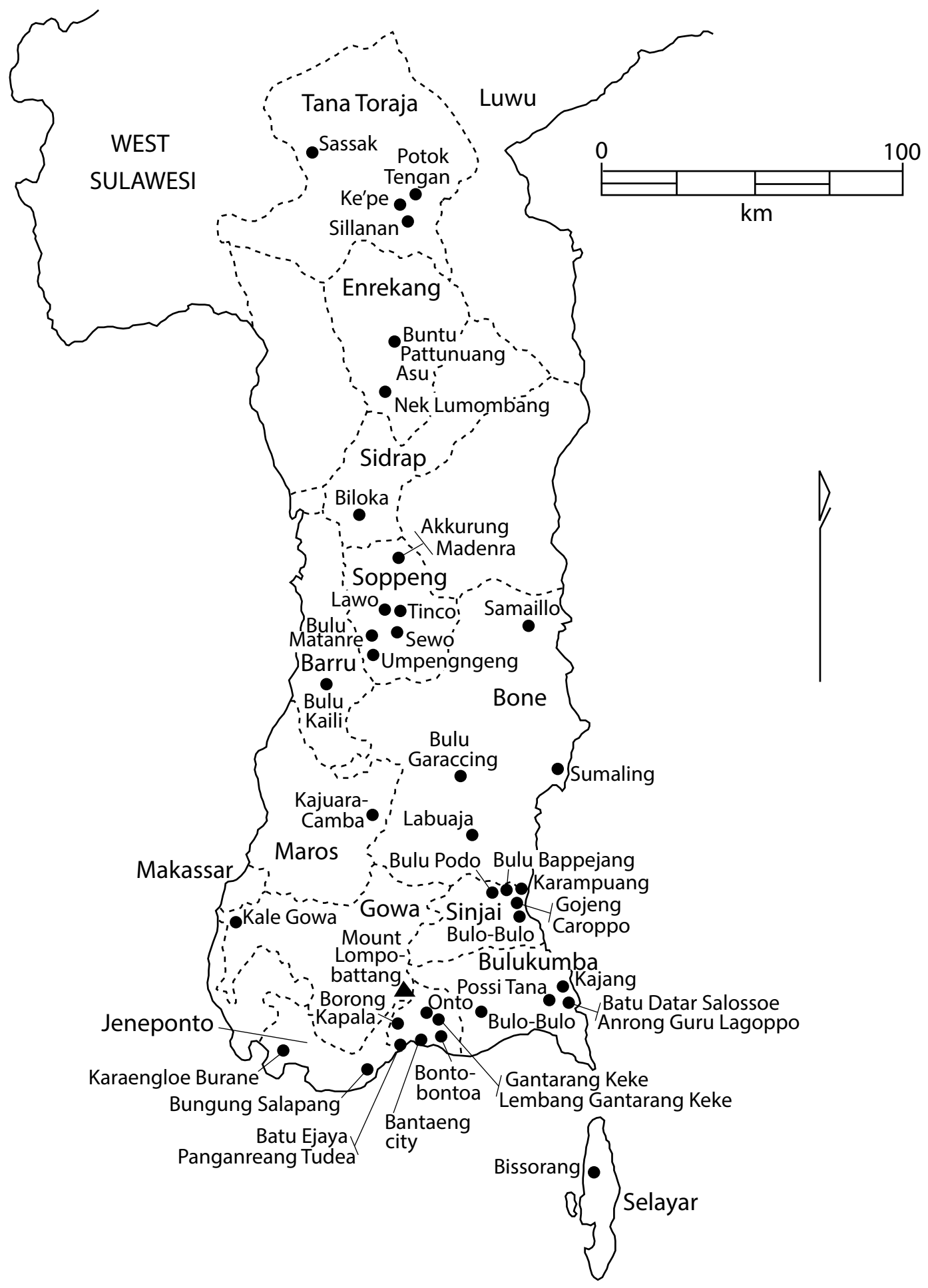

Figure 18.1: Relevant place names in South Sulawesi including district boundaries (dashed). Sources: Caldwell and Bougas (2004); Nayati (2005); Duli (2008); Hasanuddin University (2013). 
Bantaeng is a minor administrative centre today, but was of greater importance during the early history of South Sulawesi. When the VOC targeted Bantaeng during its assault on Makassar, the VOC commander described Bantaeng as a large, prosperous city that was a major riceproducing centre for Makassar (Andaya 1981:75-76). Bantaeng was also known to the eastern Javanese empire of Majapahit in AD 1365, as recorded in a poem that documented its existence alongside four other South Sulawesi places (Robson 1995). This poem specifically linked Bantaeng to the reportedly less prominent places of Luwu (located at the northeast of the peninsula) and 'Uda', which probably was then based along the Cenrana River (Caldwell and Wellen 2017). Local looters have been active in plundering imported ceramics from Bantaeng's pre-Islamic cemeteries, including 13th/14th-century wares from Bantaeng city and the archaeological sites of Benteng Batu Terang, Borong Kapala and Borong Tua to the west of Bantaeng city (Nayati 2005:Table 6).

In an influential text, Bougas (1998) examines the importance of South Sulawesi and Bantaeng's role in the region's pre-Islamic history. He uses a number of sources to produce this work including archaeological surveys in 1995 and 1996, which include maps and descriptions of the Onto site, interviews with local looters who have pilfered grave goods such as high-fired ceramics, ancient texts containing myths and legends of the time, and observations on pre-Islamic rites that have survived to the present day. This paper will develop on Bougas's work by:

(a) incorporating relevant literature postdating 1998

(b) summarising information obtained during interviews on the legends, mythology, toponyms and local beliefs as to the significance of Onto in the origins of the Bantaeng kingdom

(c) describing results from an archaeological survey conducted as part of this research on Onto

(d) discussing the prehistoric origins of the tradition of megaliths documented at Onto and other early historical sites in South Sulawesi.

\section{Description of the Onto site}

\section{Location}

Onto lies in Balla Tujua lingkungan or kampung (kampong), Kelurahan (Village) Onto, Kecamatan (Subdistrict) Bantaeng, Kabupaten (District) Bantaeng in South Sulawesi province. It lies in the hills about $12 \mathrm{~km}$ north of Bantaeng township at an altitude of 800 metres above sea level ( $\mathrm{m}$ asl), with geographical coordinates of $5^{\circ} 28^{\prime} 42.8^{\prime \prime} \mathrm{S} 119^{\circ} 58^{\prime} 33.3^{\prime \prime} \mathrm{E}$. Access to the site is facilitated by a four-wheel drive track, which connects the site to an asphalt road.

The site is surrounded by a settlement and gardens with field houses. Outside of these maintained areas, the vegetation is a dense mixture of self-generating and agricultural flora. The identified flora includes teak (jati), banyan, cacao, kapok, breadfruit, mango and langsat trees, coconut and banana palms, rattan, vines and sundry weeds. According to the local community's beliefs, the vegetation may not be cleared because felling the trees could wreak havoc.

The topography of the area is generally undulating with sharp breaks in some places and andesite rock outcrops. The soil is dark brown and generally wet from interspersed springs and streams.

\section{Overview of mythological associations}

It became apparent during interviews that Onto is believed to be the source of power of the Bantaeng royal lineage, with pre-Islamic origins. Onto is a traditional law area, and despite the community's formal conversion to Islam, traces of their traditional patuntung beliefs persist 
(Nayati 2005:268). The patuntung belief system emphasises dutiful observation of the traditional customs and precepts bequeathed by the ancestors including reverence for the ancestors (Rössler 1990). According to local community leaders, the Tomanurung (heavenly founding figure) of central Bantaeng descended from the sky at Onto to resolve the prevailing social confusion (Ulaen 1978:21-39). There he met the seven brothers who became the Karaengloe (great rulers) of Bantaeng, Gantarang Keke (eastern Bantaeng), Kajang, Luwu, Gowa, Bone and Solo in Java (Bougas 1998). The story of the seven Karaengloe brothers is commemorated at the site by seven miniature houses, where traditional ceremonies were performed. The Balla tujua hamlet, which means 'seven houses', is named for it. The site is also known by the local community as lalang bata, which means 'inside the fort'.

\section{Physical description}

In general terms, the Onto site runs along a north-south tending ridge top (see Figure 18.2). Surveys have documented a considerable variety of structures including the lalang bata fort, Balla tujua (seven houses), Barugayya festival seat, Bonto-bontoa (high point), main stone altar, Batu Pallantikang royal installation stones, Toddo ballanga, batu mentenga menhirs and graves (pre-Islamic and Islamic). The ceremonial associations of the Onto structures have been noted by previous observers (Ulaen 1978; Bougas 1998; Nayati 2005) as well as during the author's survey, although there has been no direct witnessing of the associated ceremonies in any of these cases.

\section{Lalang bata}

The lalang bata is a stacked arrangement of andesite stones, around $1 \mathrm{~m}$ high, that circumscribes most of the Onto structures (Figure 18.2). It is difficult to determine the original outline of this arrangement as it has collapsed in some places. The shape appears approximately rectangular following the hilltop's north-south contours, although the corners of the construction could not be ascertained during the survey. The estimated diameters are $125 \mathrm{~m}$ north-south and $150 \mathrm{~m}$ east-west. The stones included in the construction were likely collected from the local andesite outcrops. They have variable dimensions with no evidence of shaping.

Our survey team was informed that the old fort walls are the staging ground for a local ceremony known as the A'dete Babang. In this ceremonial offering to the Karaengloe, a procession walks around the fort with sacrificial animals and other ceremonial items. The ceremony is usually led by a dukun (shaman) who has supernatural powers that enable communication with the magical forces of nature. This shaman is a woman called the pinati by the local community.

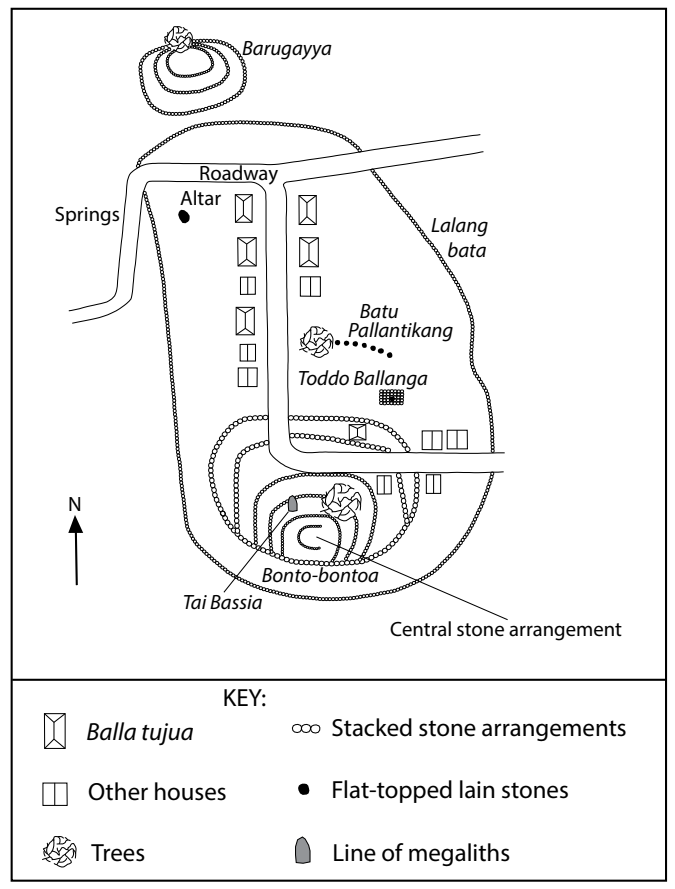

Figure 18.2: Map of Onto site (not to scale). Source: Adapted from Bougas (1998:104). 


\section{Balla tujua}

Balla tujua refers to seven miniature stilt houses erected at various times inside the lalang bata. These houses had a north-south orientation following the direction of the sea from the mountains. There were three buildings aligned on the east, three others aligned on the west and one in the middle (Ulaen 1978:17; Tuti 1991:23). More recently, six modern houses (along with some other modern houses) were built to replace the Balla tujua, but they do not replicate the Balla tujua that they replaced.

The function of the Balla tujua is to symbolise the houses of the seven brothers who ruled the domain. Accordingly, each house is named for the area that the brother ruled - that is, Balla of the Law of Bantaeng, Balla of the Law of Bone, and so on. The original function of the Balla tujua was to be the place of residence for the pinati who conducted the sacred ceremonies. According to custom, every house sheltered a family and the head of the household or his wife served as the ceremonial master (Ulaen 1978:17).

\section{Barugayya}

The Barugayya festival seat is a three-stepped terrace that lies immediately north of the lalang bata boundary (Figure 18.2). The top terrace roughly $5.5 \mathrm{~m}$ in diameter. The middle terrace is $4.5 \mathrm{~m}$ from the edge of the top terrace to its south side and $3.5 \mathrm{~m}$ on its east and west sides. The lower terrace is $5.5 \mathrm{~m}$ from the edge of the middle terrace at its south end and $3.5 \mathrm{~m}$ on the east and west sides. The complex includes a stone altar propped up by stacks of small stones.

The Barugayya terraces are built from locally collected andesite stones of various sizes ranging from $17 \mathrm{~cm}$ to $1 \mathrm{~m}$ in length. These stones have not been altered before being arranged to form the edges of each terrace. The top terrace has a consistent wall height of $65 \mathrm{~cm}$. The arrangement is broken in places where stones have gone missing. At times, members of the local community have carried away stones from the lowest terrace to make garden walls.

The Barugayya is used in a series of ceremonial processions for praying to the Karaengloe. During our survey in October 2008, remnants of these ceremonies were still visible including coconut shells, wicker baskets and coconut fruits at the eastern side, which marks the entrance gate to the upper terrace of the Barugayya.

\section{Bonto-bontoa (Pocci Butta)}

Bonto-bontoa refers to the ring-shaped stone arrangements located on the high point of the southern side of the site, in a complementary relationship to the Barugayya at the north. There are five of these stone rings, with a similar terrace construction to the Barugayya. The southern section of the site is on a steep slope, and the terraces lead to the central part of the site. The breadth of the uppermost stone ring is $3.5 \mathrm{~m}$ east-west and $7.5 \mathrm{~m}$ north-south. Its distance from the next (fourth) stone ring is $4.2 \mathrm{~m}$ and the difference in height is $55 \mathrm{~cm}$. The fourth stone ring has a banyan tree, which is revered as a holy tree by the local populace. The distance from the fourth level and the third stone ring is $4 \mathrm{~m}$ with a difference in height of $65 \mathrm{~cm}$. The distance between the third and second stone ring is $7 \mathrm{~m}$ with a height difference of $47 \mathrm{~cm}$. The distance from the second to the lowest stone ring is 11 with a difference in height of $26 \mathrm{~cm}$. The base level is roughly $63 \mathrm{~m}$ east to west and $37 \mathrm{~m}$ from north-south.

As with the Barugayya, the Bonto-bontoa terraces are constructed with unshaped andesite blocks. On the west side, the natural stones include both rounded and tapered shapes, individually placed or stacked on each other in an irregular way. According to local beliefs, the round stones are female symbols and the tapering stones are male symbols (Bougas 2007). 


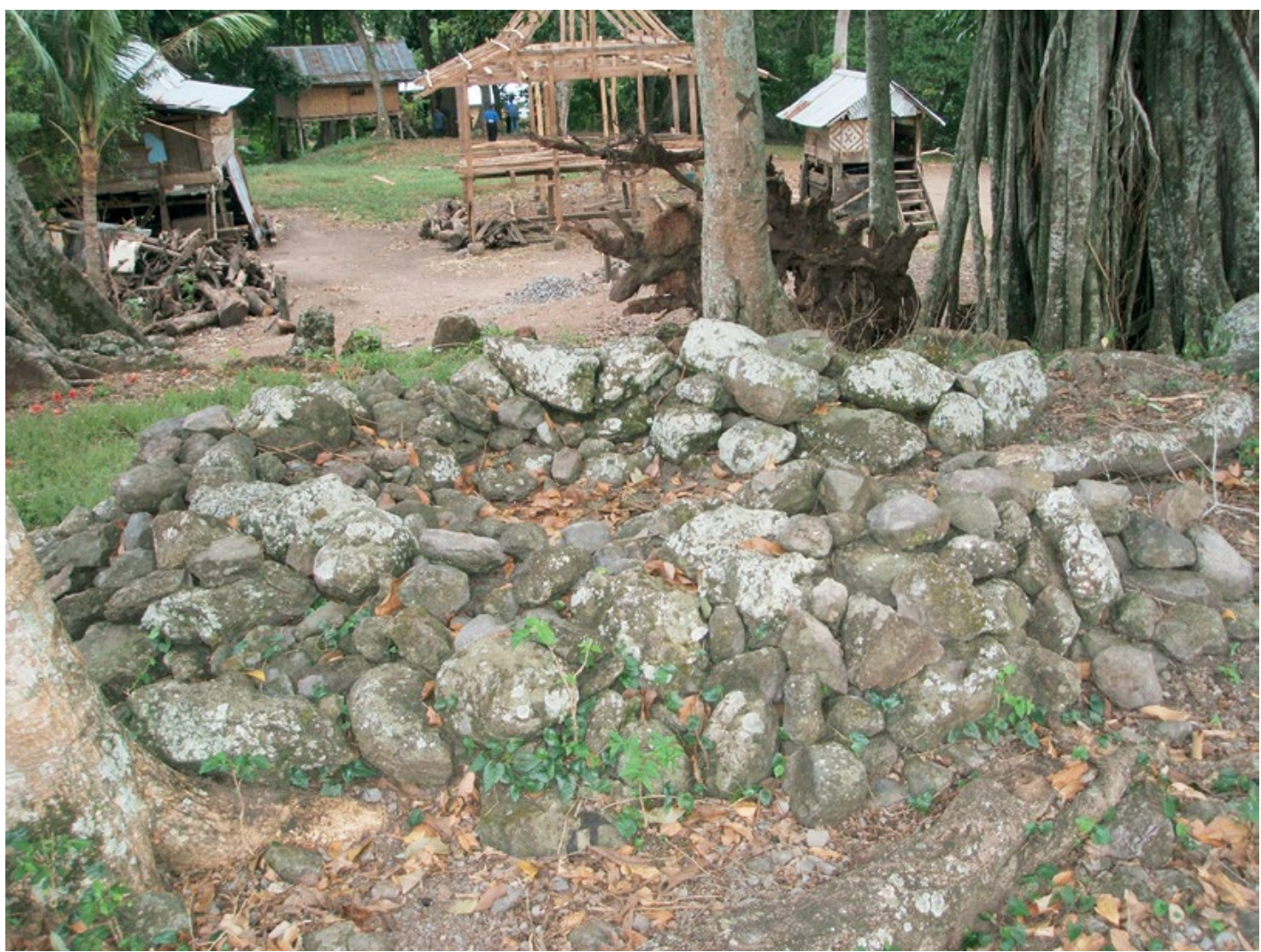

Figure 18.3: Ring-shaped pile of stones at the Bonto-bontoa peak.

Source: Akin Duli.

A considerable portion of these terraces are degraded from use of the stones for the adjacent asphalt road, yards and houses. One feature that remains whole is a ring-shaped arrangement at the peak, which is a centre for Karaengloe worship (Figure 18.3). The rocks that make up the circle are sandstone as well as andesite, with dimensions between $10 \mathrm{~cm}$ and $30 \mathrm{~cm}$. There is an entrance to the circular feature on the east side. The open space in the centre is $2.5 \mathrm{~m}$ wide.

\section{Stone altar}

The main stone altar is a natural block of stone with a flattish top located to the west side of the lalang bata (Figure 18.2). It is $2.8 \mathrm{~m}$ long, $1 \mathrm{~m}$ high and $1.8 \mathrm{~m}$ wide. Tree roots have penetrated a crack in the altar, widening the split and causing the altar to divide.

\section{Batu Pallantikang}

The Batu Pallantikang, or royal inauguration stones, consist of seven rocks laid in a row from west to east. They served as the place for the installation of the ruler (jannang) of Onto and its six subsidiaries, symbolised by the Balla tujua. These seven stones (Figure 18.4) have naturally flat surfaces and are arranged between $25 \mathrm{~cm}$ and $37 \mathrm{~cm}$ apart. Their breadth varies between $23 \mathrm{~cm}$ and $65 \mathrm{~cm}$ and their width between $7 \mathrm{~cm}$ and $27 \mathrm{~cm}$. The third and sixth stones from the west are dakon (pockmarked) stones with 12 regularly spaced shallow indentations on their surface. The sixth stone also has long, irregular incisions across its short axis with a depth of $0.4 \mathrm{~cm}$ to $0.9 \mathrm{~cm}$. According to an informant, these incisions symbolise the number of rulers who have been inaugurated. However, this report should be treated with caution because if the incisions did symbolise all the inaugurated jannang, a more regular pattern might be expected. 


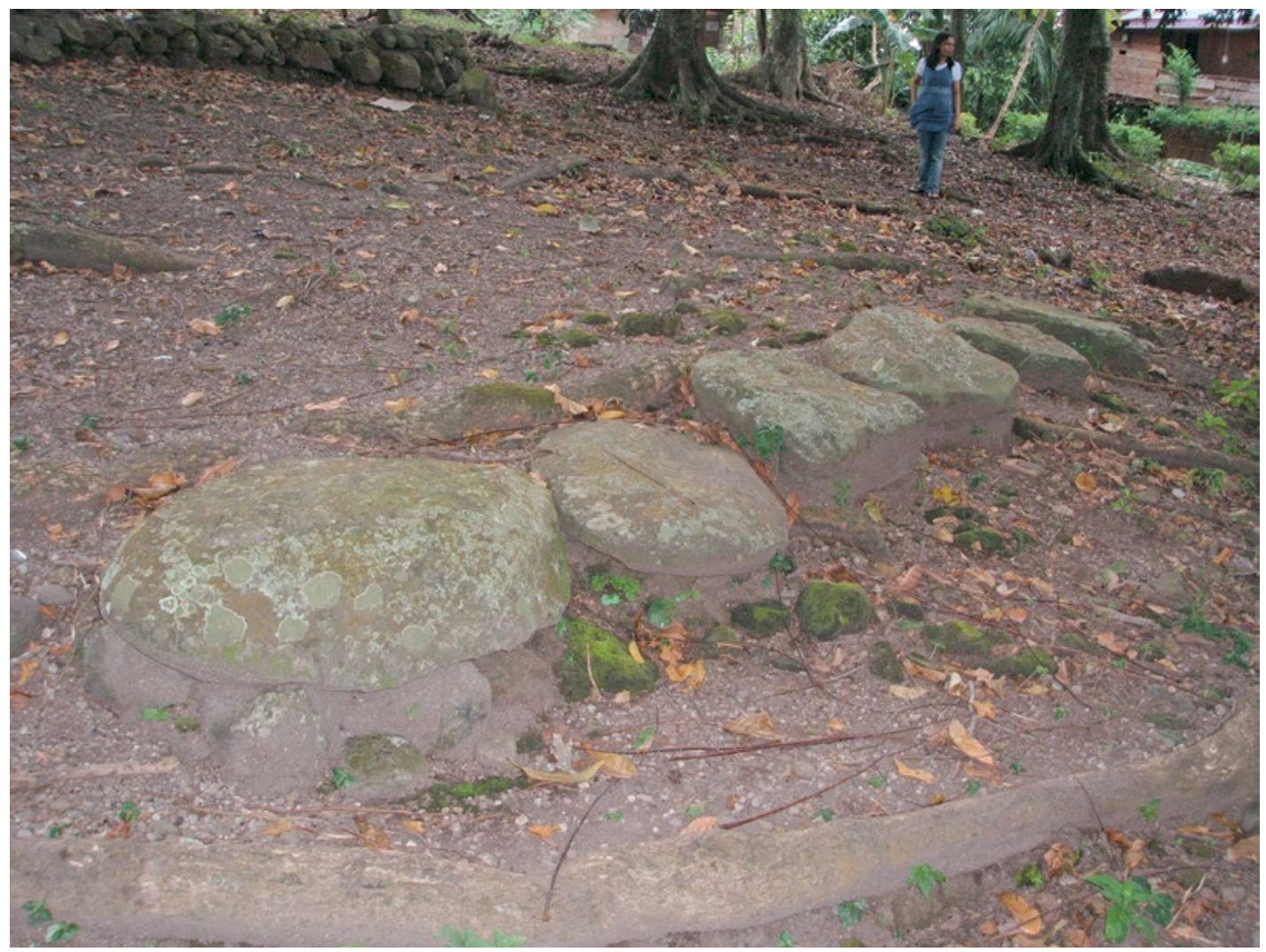

Figure 18.4: Batu Pallantikang.

Source: Akin Duli.

\section{Toddo Ballanga}

The Toddo Ballanga is a stack of andesite stones with a diameter of $97 \mathrm{~cm}$. The size of the stones varies between $20 \mathrm{~cm} \times 10 \mathrm{~cm}$ and $30 \mathrm{~cm} \times 20 \mathrm{~cm}$. The stack is surrounded by a rectangular arrangement of stones that is $2 \mathrm{~m}$ in breadth and $1.9 \mathrm{~m}$ in width. An attached wooden rail with coconut fronds runs around the stone arrangement. The Toddo Ballanga is positioned $1 \mathrm{~m}$ north of the widest stone circle of the Bonto-bontoa (basal stone ring) and $3 \mathrm{~m}$ from Batu Pallantikang (inauguration stones). A flat-topped stone altar is located in the centre (Figure 18.2).

According to the local community, the Toddo Ballanga is where the Tomanurung descended from the sky, making it an important monument for Karaengloe homage. At the time of our survey, the remains of offerings were present inside the fence, including basket wickers, coconut fruits and flowers.

\section{Batu mentenga}

Standing stones (menhirs) are called batu mentenga by the local community. There are two locations with menhirs at the site. The first includes a line of six menhirs between the second and third Bonto-bontoa stone arrays, and the second consists of a single menhir near the western border of the lalang bata (see Figure 18.2). The single megalith, or monolith, serves as the seating place for the series of Karaengloe homage ceremonies. Its height is $97 \mathrm{~cm}$ and its maximum diameter is $52 \mathrm{~cm}$, becoming thinner towards the top. 


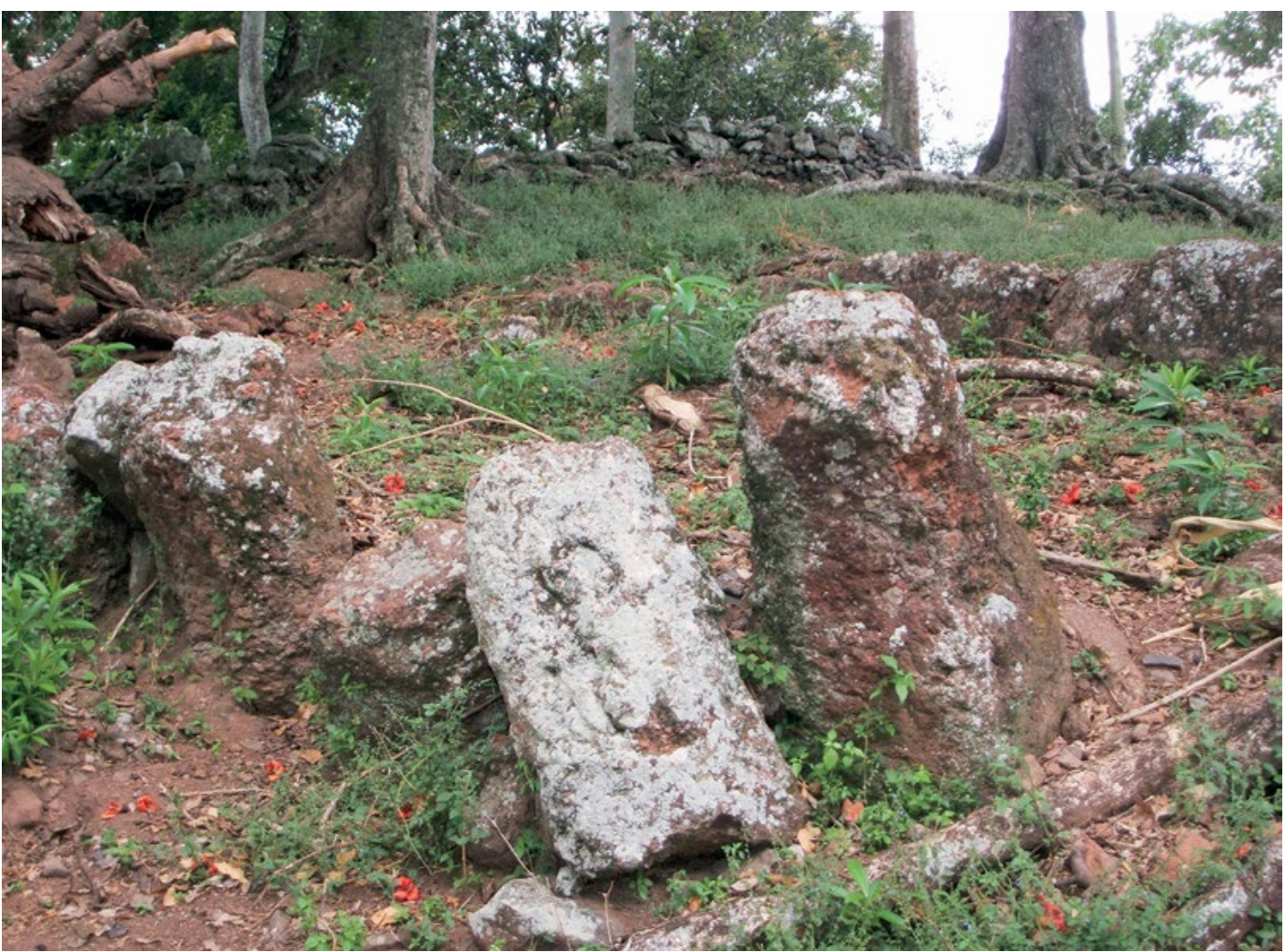

Figure 18.5: Tai Bassia line of menhirs.

Source: Akin Duli.

The six menhirs in a line, all of which are andesite, have partially fallen over (Figure 18.5). They have their natural shape, and their dimensions are variable. The westernmost is $1 \mathrm{~m}$ tall and has a diameter of $46 \mathrm{~cm}$. Proceeding east, we find the other menhirs are respectively $96 \mathrm{~cm}$ tall with a diameter of $39 \mathrm{~cm}, 56 \mathrm{~cm}$ tall with a diameter of $38 \mathrm{~cm}, 86 \mathrm{~cm}$ tall with a diameter of $39 \mathrm{~cm}, 75 \mathrm{~cm}$ tall with a diameter of $32 \mathrm{~cm}$, and $68 \mathrm{~cm}$ tall with a diameter of $36 \mathrm{~cm}$. The local community calls them Tai Bassia, which means iron rust. According to local sources, there used to be seven menhirs (the same number as for the Balla Tujua), but one was carried away to help build the road.

\section{Cemetery complex}

A cemetery complex containing both Islamic and pre-Islamic graves lies to the south of the lalang bata. The characteristic feature of the pre-Islamic graves is their form as a pile of stones with an east-west orientation (Bougas 1998:106; Nayati 2005).

\section{Distribution of surface fragments}

The fragments found on the ground surface during the survey are dominated by sherds of earthenware pottery but also include porcelain sherds. The sherds are concentrated within the lalang bata, and do not extend up the hill slope to the north nor to the east or the west. They do, however, reach across the south side of the lalang bata towards the foot of the hill. Here our survey came upon looter's holes, which still have freshly broken, imported ceramic sherds. This southward-trending distribution of the earthenware and imported ceramic sherds reflects the landscape's morphology. In this area, the slope is gentle and there is closer access to the river. Thus, it appears that the area to the north, east and west of the lalang bata was not occupied owing to difficulties of access and freshwater availability. 
Preliminary analysis of the Onto earthenware pottery has identified rim, body and base fragments from a range of forms including plates, bowls, cooking pots and barrel-shaped jars. An earlier study on imported ceramics found at Onto dates them to the 16th-17th centuries (Nayati 2005:245). Occupation at Onto clearly spanned the transition to Islam as reflected by its cemetery complex with the presence of both pre-Islamic and early Islamic graves.

\section{Social and cultural aspects of the Onto megaliths}

The prominent peak of Mount Lompobattang, which lies at the source of Bantaeng's rivers and is associated with Bantaeng's origin myths (Bougas 1998), is situated to the north of the site. The two largest megalithic structures at Onto, the Barugayya and Bonto-bontoa, form a pair at the far north and south of the site. The site's layout in general reflects a micro-cosmos oriented north to south between the mountains and sea. According to Mahmud et al. (2007:80), this local conception of the cosmos invokes a parallel with the human head, whose frontal or upper interior part is believed to be the placed to be revered, and the holy place where the ancestors, who have risen to the status of gods, reside. This interpretation reflects the view of Soejono (1984) that the tradition of megaliths in Indonesia is associated with paying homage to the ancestors.

The cosmological analogy extends to the ring-shaped stone arrangement at Bonto-bontoa, the centre of local Karaengloe worship. The pinati would enter the stone arrangement from the east with the procession following from east to west. The direction of the procession thus mimics that of the sun across the sky. This celestial passage of the sun is believed to symbolise the human life cycle from birth (sunrise) to death (sunset), and also the passage of the deceased from the state of recently passed away to the realm of the ancestors (alam puya) (Bougas 2007; Mahmud et al. 2007).

Megalithic constructions, varying from single standing stones to more complex structures, are found widely across Indonesia. The oldest megaliths perhaps functioned as grave markers including dolmens (stone tables on upright pillars), stone burial chests and chambers, sarcophagi, kalamba burial receptacles (Central Sulawesi), waruga (North Sulawesi), stone stalls and circular rings. At these burial places there are usually several other megaliths that venerate the ancestors, such as menhirs, statues of the ancestors, stone mortars (batu lumpang and batu lesung), dakon stones, decked stones, stone walls and stone-lined paths (Hasanuddin 2015). In addition, there are some megaliths that connect the population with the locally venerated ancestors. These include altars that have been used both as thrones by rulers and as a holy place for paying homage to the ancestors through meetings and ceremonies. Other examples are the stone mortars placed on the corners of dry gardens or wet paddy fields that are believed to channel supernatural energy to boost crop production (personal observations).

The following sections discuss some possible purposes of the Onto megaliths, which include stone terraces, ring-shaped stone arrangements, menhirs, stone altars and the royal inauguration stones, which include two dakon stones.

\section{Stepped terraces}

Stepped terraces are constructions of stones arranged into terraces or steps, usually with three, five or seven levels. They are found at several megalithic sites in South Sulawesi, usually located at the foot of a hill, on a hilltop (e.g. Onto) or on holy peaks (e.g. Bulu Matanre; Kallupa et al. 1989). They mark the transition from the lower, everyday outer levels to the elevated, sacred levels on the inside. Other megaliths associated with the stepped terraces would have had different functions during the ceremonial processions along the stepped terraces. At Onto, 
the stepped terraces had a communal function for ritual ceremonies involving the mass gathering of all community members reflecting the social strata of the entire community. At another site with stepped terraces on an earthen mound, Karaengloe Burane in Jeneponto (Caldwell and Bougas 2004), the stepped terraces mark the approach to a ring-shaped stone arrangement that circumscribes a square stone arrangement, which is a focus of local Tomanurung rites.

\section{Ring-shaped stone arrangements}

The function of the ring-shaped arrangement of stones at Bonto-bontoa was to provide a place to worship the ancestral spirits. The pairing of round stones (vagina $=$ female) with cylindrical stones (phallus = male) symbolises the meeting between the 'Upperworld' of the sky and celestial bodies and the 'Underworld' of the earth and sea, which gave birth to the 'Middleworld' where humanity resides. This 'Austronesian cosmology' (see Gibson 2005:50-51) aligns with the local belief that the Bonto-bontoa (Pocci Butta) is the centre of the settlement (kampung) — that is, the natural centre of local microcosmic power as a symbol of the macrocosmic world at large. Fittingly, this monument commemorates the Karaengloe who became the ancestors of Bantaeng's leaders after meeting with the Tomanurung.

Onto's second ring-shaped stone arrangement, the Barugayya, functioned as the place for conferences between the community leader and members, where the leader would be positioned inside the circle and the other community members towards the outside.

One of the most important of the ritual sites in western Bantaeng, Borong Kapala, also features stone arrangements, but further details are unavailable because the local inhabitants refused access for archaeological documentation (Nayati 2005:259).

\section{Menhirs}

Menhirs are widely distributed across Indonesia. Amongst traditional communities that continue their megalithic culture, menhirs are involved in practical matters such as displays of social status, but this use is still strongly tied to a belief in the megaliths' connections with the spirits of the ancestors (e.g. Bonatz 2002). The menhirs at the Onto site are not well understood by the local community, but their explanations centre around the continuation of the traditional Karaengloe ceremonies. The menhirs are also associated with veneration for bygone iron workers (taka bessia), their unique ability to work iron symbolised by the peculiar shapes of the assembled menhirs (Bougas 1998). In South Sulawesi, menhirs are far more a feature of archaeological sites in Bugis- than in Makasar-speaking areas (Hasanuddin 2015), although a large menhir originally $2 \mathrm{~m}$ high (now lying on its side) was recorded near the royal installation stones of the Kale Gowa rulers of Makassar (Bulbeck 1992).

\section{Stone altars}

Stone altars are usually associated with other megaliths and, like menhirs, they are common across Indonesia. They are flat-lain stones, sometimes supported by feet of stacked stones. These raised stone altars have been found widely across the South Sulawesi peninsula (Duli 2008; Hasanuddin University 2013), not only at Onto (within the Barugayya) but also at Nek Lumombang and Buntu Pattunuang Asu (Enrekang), Biloka (Sidrap), Sewo, Lawo, Tinco, Umpengngeng, Akkurung, Madenra (Soppeng), Bulu Kaili (Barru), Samaillo, Labuaja, Bulu Garaccing and Sumaling (Bone), Kajuara-Camba (Maros), Gojeng, Karampuang, Caroppo, Bulu Podo, Bulo-Bulo and Bulu Bappejang (Sinjai), Bungung Salapang (Jeneponto), Lembang Gantarang Keke and Gantarang Keke (Bantaeng), Possi Tana, Bulo-Bulo, Batu Datar Salossoe and Anrong Guru Lagoppo (Bulukumba) and Bissorang (Selayar). 
In the Tana Toraja regency to the north of the peninsula, raised stone altars functioned as places to present offerings during thanksgiving harvest ceremonies at sites such as Sillanan, Potok Tengan, Ke'pe and Sassak (Duli 1999). At Onto, the stone altar at the Toddo balanga served to honour the Karaengloe. The stone altars at Lembang Gantarang Keke are associated with various aspects of veneration of the local Tomanurung, including the location where he descended from heaven, his seating place and the spot where offerings of sugar palm were prepared for him; while a large stone at Gantarang Keke is believed to mark the site where this Tomanurung returned to heaven (Bougas 1998:93-95).

\section{Royal inauguration stones}

The other flat stones at Onto form a row of stones for the installation of rulers at the Batu Pallantikang. Two of the installation stones are dakon, which may have been used for keeping a count of 'days of good fortune' or to confirm predictions made by traditional law leaders. The dakon stone with incisions may also have functioned to impart magical power to blades that were sharpened across its surface.

\section{Chronology of the Onto site}

Bantaeng has a lengthy occupation history as demonstrated by the cave sequences at Panganreang Tudea and Batu Ejaya. These deposits include a Mesolithic layer dating back to at least the 3rd millennium BC and a Neolithic occupation layer marked by the appearance of earthenware pottery. The Batu Ejaya decorated pottery is associated with a ${ }^{14} \mathrm{C}$ date on charcoal of c. AD 1000. This date coincides with the approximate age of the Bonto-bontoa site in eastern Bantaeng, where similar decorated pottery, metal wares and 21 imported carnelian beads were excavated (Bulbeck 2004). Tuti (1991:50) proposed that the megalithic remains at Onto distinguish it as an ancient monumental site (1st millennium BC) according to Heine Geldern's (1945) classification of Indonesian megaliths into old (Neolithic) and more recent (Metal Age) examples. However, Heine Geldern's schema was problematic as it was not supported by any direct dates (Bellwood 1978; Soejono 1984) and is now disproved with the recent availability of ${ }^{14} \mathrm{C}$ dates associated with megaliths (Hasanuddin 2015).

It is unlikely that initial occupation at Onto preceded the 15th century (Nayati 2005:268). The significance of the Onto site for the origins of the Bantaeng royal line are strongly attested in local legendary accounts, both oral and written (Bougas 1998), but this line includes only six rulers who preceded Bantaeng's 17th-century conversion to Islam, including a probably 16th-century antiquity for the Tomanurung who reportedly descended at Onto (Nayati 2005:Table 3). For earlier evidence of chiefly authority in Bantaeng, we would need to turn to Lembang Gantarang Keke and Gantarang Keke in eastern Bantaeng, which were established regional centres in the 11 th or 12 th century $\mathrm{AD}$, preceding the 13 th-century evidence found from looted pre-Islamic graves at these sites, including Chinese porcelain and stoneware of Song Dynasty antiquity (Bougas 1998). Moreover, Lembang Gantarang Keke and Gantarang Keke are also associated with a Tomanurung site whose sacred status is more widely acknowledged across Bantaeng than its Onto counterpart (Nayati 2005:243). Certainly, by the 14th century, corresponding to the Javanese reference to Bantaeng noted in the Introduction, Chinese (Yuan Dynasty) imported pottery was widespread across Bantaeng, political centralisation was more developed and Bantaeng appears to have become an important staging post for the trade in spices from the Moluccas to Java, but the participation of Onto/Bantaeng city in this development does not appear to have preceded the 15th century (Bougas 1998:119). 


\section{Discussion and Conclusions}

When aligned within the overall pattern of Bantaeng's early development (Bougas 1998; Nayati 2005), the Onto site exemplifies the megalithic monuments and Tomanurung veneration found at early historical sites in western, central and eastern Bantaeng. Additionally, its porcelain and stoneware surface fragments suggest that it produced commodities to exchange for imported pottery. Indigenous texts and local traditions point to Onto as a point of reference for the traditional agrarian communities residing in central Bantaeng with their belief system based on traditional patuntung precepts. In summary, it continued a system for the recognition of chiefly authority first in evidence in eastern Bantaeng, but which expanded in late pre-Islamic times with the integration of western, central and eastern Bantaeng into a single polity (Bougas 1998).

The orientation of the Onto monuments running east-west and north-south reflects a cosmology found more widely across traditional Bugis-Makasar societies. This configuration follows the cosmological conception that the sun's rising in the east symbolises light, happiness, success and the sources of life, whereas the sun's setting in the west represents darkness, grief, difficult matters and death (Bougas 2007). The Onto community associates this east-west orientation with the phases of life, for the sun rises in the east and crosses over the hilltop at its zenith before finishing its journey at dusk, the symbol of death. As for the north-south arrangement, Mount Lompobattang to the north is compared with the human head, the frontal part where people receive adoration, and the holy place where the Karaengloe spirit survives as a god. The microcosmic kampong centred at Bonto-bontoa (Pocci Butta) is the template for the world at large, a model for how the kampong patuntung residents should fit within the world's divinely ordained qualities and cosmological design (Mahmud et al. 2007).

\section{Acknowledgements}

The constructive comments of two anonymous referees are gratefully acknowledged.

\section{Author biography}

Akin Duli Archaeology Program, Faculty of Law and Culture, Hasanuddin University, Makassar, South Sulawesi, Indonesia

\section{References}

Andaya, L.Y. 1981. The Heritage of Arung Palakka: A History of South Sulawesi (Celebes) in the Seventeenth Century. Verhandelingen van het Koninklijk Instituut voor Taal-, Land- en Volkenkunde 91. The Hague: Martinus Nijhoff.

Bellwood, P. 1978. Man's Conquest of the Pacific. Sydney: Collins.

Bonatz, D. 2002. Megaliths on Nias: The retention of identity. Indonesia and the Malay World 30(88):253-276. doi.org/10.1080/1363981022000064357 (accessed 5 June 2018).

Bougas, W.A. 1998. Bantayan: An early Makassarese kingdom, 1200-1600 AD. Archipel 55(1):83-123. doi.org/10.3406/arch.1998.3444.

Bougas, W.A. 2007. Gold looted and excavated from late (1300 AD-1600 AD) pre-Islamic Makassar graves. Archipel 73(1):111-166. doi.org/arch_0044-8613_2007_num_73_1_3877 (accessed 5 June 2018). 
Bulbeck, F.D. 1992. A Tale of Two Kingdoms: The Historical Archaeology of Gowa and Tallok, South Sulawesi, Indonesia. Unpublished PhD thesis, School of Archaeology and Anthropology, The Australian National University, Canberra. www.oxis.org/theses/bulbeck-1992.pdf (accessed 5 June 2018).

Bulbeck, D. 2004. Divided in space, united in time: The Holocene prehistory of South Sulawesi. In S. Keates and J.M. Pasveer (eds), Quaternary Research in Indonesia, pp. 129-166. Modern Quaternary Research in Southeast Asia, Volume 18. Leiden: A.A. Balkema.

Caldwell, I. and W.A. Bougas. 2004. The early history of Binamu and Bangkala, South Sulawesi. Bijdragen tot de Taal-, Land-en Volkenkunde 160(4):456-510. doi.org/10.1163/22134379-90003720 (accessed 5 June 2018).

Caldwell, I. and K. Wellen. 2017. Finding Cina: A new paradigm for early Bugis history. Bijdragen tot de Taal-, Land-en Volkenkunde 173(2/3):296-324. doi.org/10.1163/22134379-17302004 (accessed 5 June 2018).

Duli, A. 1999. Bentuk-bentuk Penguburan Orang Toraja, suatu Studi Etnoarkeologi. Presentation at the Pengetahuan Ilmiah Arkeologi VIII congress, Yogyakarta.

Duli, A. 2008. Bentuk dan peranan budaya megalitik pada beberapa situs di Kabupaten Bantaeng. Walennae 10(14):19-43.

Gibson, T. 2005. And the Sun Pursued the Moon: Symbolic Knowledge and Traditional Authority among the Makassar. Honolulu: University of Hawai'i Press.

Hasanuddin. 2015. Kebudayaan Megalitik di Sulawesi Selatan dan Hubungannya dengan Asia Tenggara. Unpublished PhD thesis, Centre for Archaeological Research Malaysia, Universiti Sains Malaysia, Kuala Lumpur. www.oxis.org/theses/hasanuddin-2015.pdf (accessed 5 June 2018).

Hasanuddin University. 2013. Judul Skripsi Sejarah Arkeologi II. www.gurusejarah.com/2013/03/judulskripsi-sejarah-arkeologi-ii.html (accessed 5 June 2018).

Heine Geldern, R. 1945. Prehistoric research in the Netherlands Indies. In P. Honig and F. Verdoorn (eds), Science and Scientists in the Netherlands Indies, pp. 129-167. New York: Board for the Netherlands Indies, Surinam and Curaçao.

Kallupa, B., D. Bulbeck, I. Caldwell, I. Sumantri and K. Demmanari. 1989. Survey Pusat Kerajaan Soppeng 1100-1986 [Survey of the Capital of Soppeng Kingdom 1100-1986]. Final Report to the Australian Myer Foundation, Privately published in Canberra, ACT. www.oxis.org/books/soppeng-1986.pdf (accessed 5 June 2018).

Mahmud, M.I., A. Duli, M.N.A. Thosibo and B. Hakim. 2007. Bantaeng, dari Masa Prasejarah ke Masa Islam. Makassar: Masagena Press.

Nayati, W. 2005. Social Dynamics and Local Trading Patterns in the Bantaeng Region, South Sulawesi (Indonesia) circa 17th Century. Unpublished PhD thesis, The Southeast Asian Studies Programme, National University of Singapore, Singapore. www.oxis.org/theses/widiya-nayati-2005.pdf (accessed 5 June 2018).

Robson, S. (translator). 1995. Désawanana (Nagarakrtagamana) by Mpu Prapañca. Leiden: KITLV Press.

Rössler, M. 1990. Striving for modesty: Fundamentals of the religion and social organization of the Makassarese Patuntung. Bijdragen tot de Taal-, Land- en Volkenkunde 146(2/3):289-324. doi.org/ 10.1163/22134379-90003220 (accessed 5 June 2018).

Soejono, R.P. 1984. Sejarah Nasional Indonesia, vol. 1. Jaman Prasejarah. Jakarta: Balai Pustaka. 
Tuti, D.L.A. 1991. Peninggalan Megalitik Onto di Bantaeng. Unpublished PhD thesis, Arts Faculty, Archaeology Program, Hasanuddin University, Ujung Pandang [Makassar].

Ulaen, A.J. 1978 Onto di Bantaeng, antara Mitos dan Realitas: Studi Rintisan Antropologis Tentang Struktur Kepemimpinan Tradisional. Laporan Penelitian. Ujung Pandang [Makassar]: Pusat Latihan Penelitian Ilmu-Ilmu Sosial.

Wikipedia. 2017. Bantaeng Regency. en.wikipedia.org/wiki/Bantaeng_Regency (accessed 26 June 2017). 
This text is taken from The Archaeology of Sulawesi: Current Research on the Pleistocene to the Historic Period, edited by Sue O'Connor, David Bulbeck and Juliet Meyer, published 2018 by ANU Press, The Australian National University, Canberra, Australia.

doi.org/10.22459/TA48.11.2018.18 